IZA DP No. 6964

Aggregate Savings and External Imbalances in China

Dennis Tao Yang

October 2012

Forschungsinstitut zur Zukunft der Arbeit Institute for the Study of Labor 


\title{
Aggregate Savings and External Imbalances in China
}

\author{
Dennis Tao Yang \\ University of Virginia \\ and IZA
}

\section{Discussion Paper No. 6964 \\ October 2012}

\author{
IZA \\ P.O. Box 7240 \\ 53072 Bonn \\ Germany \\ Phone: +49-228-3894-0 \\ Fax: +49-228-3894-180 \\ E-mail: iza@iza.org
}

Any opinions expressed here are those of the author(s) and not those of IZA. Research published in this series may include views on policy, but the institute itself takes no institutional policy positions. The IZA research network is committed to the IZA Guiding Principles of Research Integrity.

The Institute for the Study of Labor (IZA) in Bonn is a local and virtual international research center and a place of communication between science, politics and business. IZA is an independent nonprofit organization supported by Deutsche Post Foundation. The center is associated with the University of Bonn and offers a stimulating research environment through its international network, workshops and conferences, data service, project support, research visits and doctoral program. IZA engages in (i) original and internationally competitive research in all fields of labor economics, (ii) development of policy concepts, and (iii) dissemination of research results and concepts to the interested public.

IZA Discussion Papers often represent preliminary work and are circulated to encourage discussion. Citation of such a paper should account for its provisional character. A revised version may be available directly from the author. 


\section{ABSTRACT}

\section{Aggregate Savings and External Imbalances in China*}

Over the last decade, the internal and external macroeconomic imbalances in China have risen to unprecedented levels. In 2008, China's national savings rate soared to over 53 percent of its GDP, whereas its current account surplus exceeded 9 percent of GDP. The current paper presents a unified framework for understanding the structural causes of these imbalances. I argue that the imbalances are attributable to a set of policies and institutions embedded in the economy. Moreover, the accession of China to the World Trade Organization has dramatically amplified the effects of these structural distortions. I document major trends in aggregate savings, investment, trade, and net foreign asset positions in China, and explore options for policy reforms aimed at rebalancing the Chinese economy.

JEL Classification: E21, O16, F32

Keywords: aggregate savings, current account, income distribution, structural distortions, trade policies, China

Corresponding author:

Dennis Tao Yang

Darden School of Business

University of Virginia

Charlottesville, VA 22903

USA

Email: YangD@darden.virginia.edu

\footnotetext{
* The author would like to thank Chi Chur Chao, Hongyi Chen, Jing Han, Dong He, Jun Ma, William Martin, Liugang Sheng, Kang Shi, Yun Wing Sung, seminar participants at The World Bank and Australian National University, and the JEP editors for constructive comments and suggestions. The author is also grateful to Chuantao Cui, Shaozhi Li, and Jessie Pang for excellent research assistance. The financial support from the Research Grants Council of the Hong Kong Special Administrative Region, China (Project Number 453008) and the research support from Hong Kong Institute of Monetary Research and the Hong Kong Institute of Asia-Pacific Studies are gratefully acknowledged.
} 
The high savings and investment rates in China have been a major driving force behind its rapid economic growth. During the 1980s and 1990s, China's high savings rates in the range of 35-40 percent of GDP were not accompanied by external imbalances: Its current account balance fluctuated within 2 percent of GDP in most of the years. However, starting around 2001, China's already high savings rate soared further and the current account surplus also rose along a steep trajectory. In 2008, the aggregate savings rate of China reached 53 percent of GDP, whereas the current account surplus exceeded 9 percent of GDP. Although the current account surplus moderated during the financial crisis, it remained at a lofty 5.2 percent of GDP in 2010 . With the accumulation of the annual current account surplus and net inflows of capital, the foreign exchange reserves of China climbed to an unprecedented level, topping \$3 trillion in March 2011. This total is nearly triple the amount held by Japan, the second largest holder of foreign reserves in the world.

This paper presents an explanation for the evolving macroeconomic imbalances in China. I argue that the extraordinarily high savings rate and current account surpluses are primarily attributable to a set of policies, institutions, and structural distortions embedded in the Chinese economy. When China joined the World Trade Organization in 2001, business climate improved and trade barriers fell dramatically, resulting in a rise in profitability of firms. However, due to a set of institutional rules that centered on export promotion and that favored firms and government over the household sector, a high 
percentage of this windfall gain of profits was either saved in the corporate sector or was collected by the government, which has not accordingly adjusted upward its social welfare spending. The result was an extraordinary upsurge in aggregate savings, along with weak domestic consumption and anemic demand for imported goods. The imbalance was made even worse by the rise in household savings, which was due to structural shifts in the labor market, incomplete social welfare reforms, and demographic changes resulting from population control policies, and by stringent pursuit of policies on export promotion. When the ill-functioning financial system of China failed to channel the increased savings to high-return production investment or consumption loans, the excess savings ended up as huge foreign exchange reserves invested in low-yielding overseas government bonds.

The macroeconomic imbalances in China pose a number of risks. The extraordinarily low consumption-to-GDP ratio implies that the rapid economic growth in China over the past decade has been mainly propelled by investments and foreign demand. Thus, sustaining growth amid declining investment efficiency or negative shocks in external demand is challenging. With foreign exchange reserves heavily invested in U.S. dollar- and euro-denominated bonds, China faces potentially enormous capital losses if the dollar and the euro depreciated. ${ }^{1}$ Moreover, as a fast-growing developing country, China should post net inflows of investments; instead, its huge savings are invested abroad earning low returns. From a global perspective, the enormous trade surplus of China is mirrored by equally large trade deficits elsewhere. Several major trading partners of China are upset, and their politicians and analysts have blamed China

\footnotetext{
${ }^{1}$ Estimates show that China held about two-thirds of its foreign exchange reserves in the US dollar and more than one-fifth in the euro in 2007. These investments earned an average 3 percent annual rate of return (Sheng, 2011).
} 
for contributing to the failure of domestic firms and the loss of jobs. Ultra-large trade deficits also are associated with economic and financial disruptions, which present threats to global macroeconomic stability.

This paper begins by documenting the trends in the balance of payments of China, including dramatic changes in the current account balance, net foreign asset positions, and the significant buildup of foreign exchange reserves. I then present the corresponding changes in national savings and investment. With these facts in evidence, I propose a unified framework for understanding the joint causes of the high savings rate and external imbalances in China. ${ }^{2}$ My explanations will first focus on an array of factors that encouraged saving across the corporate, government, and household sectors, such as policies that affected sectoral income distribution, along with factors like incomplete social welfare reforms, and population control policies. I then turn to policies that limited investment in China, thus preventing the high savings from being used domestically. Finally, this paper I will examine how trade policies, such as export tax rebates, special economic zones, and exchange rate policies, strongly promote exports. In the final section of the paper, some policy reforms for rebalancing the Chinese economy are recommended.

\section{Trends in Trade Accounts and National Savings}

Balance of payments statistics report all cross-border flows of value between a country and the rest of the world over a period of time. To document the external

\footnotetext{
${ }^{2}$ Despite a general awareness of the internal and external linkages, academic and policy research often focus on either the high savings in China or on the trade surplus and exchange rate policies. For example, Ma and Wang (2010), and Yang et al. (2012) recently conducted two surveys on the high savings rate in China. See Goldstein and Lardy (2009), and Corden (2009) for the analyses of the current account surplus and exchange rate policies of China.
} 
imbalances of China, the categories of flows are classified as current account, foreign direct investment, portfolio-and-other investment, official foreign exchange reserves, and a remaining statistical discrepancy. The sum of these components is necessarily zero.

Panel A of Figure 1 shows the current account balance of China from 1985 to 2010. As noted earlier, the trade imbalance was insignificant through the mid-1990s. In fact, deficits were recorded in some years. However, from 2001 onwards, the surplus rose along a steep trajectory, accelerating further in 2005 and reaching 10.1 percent of GDP in 2007. The other line in the figure shows that the surplus in trade of goods and services is almost identical to the current account surplus. Therefore, these two terms are interchangeably used in subsequent discussions.

Panel B of Figure 1 shows that the net capital and financial account, which consists of assets and liabilities of foreign direct investment, portfolio and other investment, exhibits similar patterns as the trade account. Although rise in the surplus occurred in the mid-1990s, the capital and financial account was more or less balanced before China joined the World Trade Organization in 2001. After that, however, the financial and capital account registered a sharp rise in surplus. The panel also shows that China notably experienced continued net inflow of foreign direct investment since the mid-1990s, being the second largest recipient of foreign direct investment after the U.S.. In the aftermath of the financial crisis of 2008 , both the net accounts of foreign direct investment and portfolio-other investment for China stood in positive territories, summing to a surplus of 4 percent of GDP.

The persistent "twin surpluses" in the current and capital accounts in the past decade have resulted in an explosion in foreign exchange reserves. In 2000, China only 
had $\$ 10.9$ billion in reserves, equivalent to 0.9 percent of GDP. The subsequent rise in currency reserves was astonishing. In 2004 alone, as Panel C shows, the yearly accumulation jumped to 10.7 percent of GDP. After reaching a peak of 13.2 percent of GDP in 2008, it hovered at around 8 percent of GDP in 2010. As a result, foreign exchange reserves topped $\$ 1$ trillion in 2006. In June 2011, total foreign exchange reserves topped $\$ 3.2$ trillion, which was approximately triple the amount held by Japan. The reserve assets of China are mostly invested in low-return U.S. government bond market.

While balance-of-payment statistics capture the cross-border flows of value in trade and capital, net foreign asset statistics provides the stock position of the economy in external financial assets and liabilities. Hence, a current account surplus translates into an increase in net foreign assets, while a current account deficit translates into a decrease in net foreign assets position. Adopting an approach similar to that of Lane and MilesiFerretti (2007), Ma and Zhou (2009) document the emergence of China as a large and rising creditor in the world. In only 10 years, the net foreign asset position of China rose substantially that the country swung from being a net debtor of approximately 6.2 percent of GDP in 2000 to a net creditor of approximately 30.5 percent of GDP in 2010 (SAFE, 2011). Foreign exchange reserves account for a lion's share of the net foreign assets, reaching 69 percent in 2010.

All economists recognize that both trade deficits and trade surpluses can bring economic gains, depending on the situation of an economy. However, large and sustained external imbalances can also be a prelude to economic adjustments that may be wrenching. Table 1 offers a global perspective on the evolution of these imbalances. For 
example, back in 1995, the "advanced economies" as a group were running trade surpluses, while the "emerging and developing economies" as a group had trade deficits. By 2000, these positions had reversed. From 2000 up through the years prior to the financial crisis in 2008, the current account deficit of the advanced economies grew enormously, as did the current account surpluses of the emerging and developing economies. In 2008, China emerged as the largest net lender with a surplus of $\$ 436.1$ billion, which is equivalent to 24.3 percent of the total trade surplus for all countries running surpluses. Germany followed a similar path, swinging from having a current account deficit of $\$ 32.6$ billion in 2000 to having a surplus of $\$ 245.7$ billion in 2008 . The sum of the current account surpluses of these two countries roughly equals the huge current account deficit of the U.S. at $\$ 689$ billion in 2008. In the aftermath of the financial crisis, China continued to have the largest current account surplus among all countries as of 2010 .

The well-known national income identity helps to explore potential connections from domestic savings to the external trade balance, by stating the accounting relationship between national public and private savings (S), domestic capital formation (I), and the current account balance (X-M):

\section{$S-I=X-M$.}

This identity has a straightforward interpretation of the situation of China: The amount earned by the trade surplus that is not consumed or invested must end up being saved. Moreover, the gap between savings and investment equals the net flow of foreign investment over time. This simply means that national savings not invested at home are invested aboard. This equation can help clarify how the serious internal and external 
imbalances have evolved in China.

Figure 2 provides the trends in aggregate savings and investment in China from 1992 to 2008, complementing the balance of payments statistics presented in Figure $1 .^{3}$ The data on flow of funds accounts contain the composition of gross domestic savings and investment by household, business, and government, and also information on income and expenditures within each of these sectors.

Panel A shows that the national savings of China moved in near-lockstep with aggregate investment in the late 1990s. However, from 2000 onwards, the aggregate savings rate increased along a steep trajectory, moving above the rate of investment. After 2004, national savings exhibited a strong upsurge at approximately 2 percentage points of GDP per year for four consecutive years, reaching a new height of 53.2 percent in 2008 , whereas the investment rate plateaued to 42 to 44 percent of GDP. The result was a huge gap between savings and investments and the corresponding increase in current account surplus from 2005 to 2008 .

Panels $\mathrm{B}$ and $\mathrm{C}$ present disaggregated information on savings and investment by corporate, household, and government sectors. On the investment side, the corporate sector contributed 6.1 percentage points out of 8.9 percentage points of the total increase in domestic investment as a percentage of GDP from 2000 to 2008. On the savings side, all three sectors contributed significantly, and rather evenly, to the 15.9-percentage-point total increase in the national savings during the period.

The explosion in the "twin surpluses" in the current and capital accounts starting

\footnotetext{
${ }^{3}$ In 1995, the National Bureau of Statistics (NBS) of China began to publish the Flow of Funds Accounts based on the physical transactions of national income accounting, covering the government, corporate, and household sectors. With a three-year lag policy, the most recent data available for analysis cover 1992 to 2008.
} 
2000 caught the Chinese government off guard. The policy target of the 11th Five-Year Plan was to achieve a balanced current account from 2006 to 2010, which differs drastically from the realized outcome. Because much is at stake with China's enormous trade surpluses, a number of studies have attempted to understand their causes. One common view is that the intervention of the exchange rate conducted by the Chinese government is the culprit for the severe trade surplus. Other causal factors include financial market imperfections, the migration of processing trade into China because of the global division of labor, and the pursuit of export-led development strategies (e.g., Yu, 2007; Goldstein and Lardy, 2009; Song et al., 2011). In his "saving glut" hypothesis, Federal Reserve Chairman Bernanke (2005) emphasizes that the changes in desired savings and investment in a region, like higher desired rates of savings in China, affect the external balances of this region and those of other countries around the world. Governor Zhou (2009) of the People's Bank of China highlights the role of high savings rate in affecting the current account surplus of China. He has expressed clear policy intention to reduce the savings ratio of China. Although these studies recognize the relevance of savings to the current account balance, they do not investigate the reasons behind the high savings rates. An even more serious challenge is deciding whether the high savings rate is the cause or effect of the current account surplus in China.

What factors sharply increased the macroeconomic imbalances in China after 2000? The next three sections consider how policies and institutions affected three factors: 1) upward pressure on an already high domestic savings rate;2) limits on investment in productive capacity; and 3) trade and exchange rate policies that promoted exports. Some of these policies and structural factors are historical legacies that were inherited 
from the central planning system, while others are more recent government policies and regulations imposed on the household and corporate sectors.

\section{The Aggregate Savings Rate of China}

The aggregate national savings rate is comprised of the savings rates of three sectors: household, firm, and government. Thus, the national savings rate can rise either because the savings rate within one or more sectors rises, or because a high-saving sector expands while a low-saving sector contracts. Based on the flow of funds data, the rising saving rate of China from 2000 to 2008 can be decomposed into three changes: a) a sharp rise in the share of the disposable income of enterprises in GDP raised the aggregate savings of China by 5.5 percentage points; b) a rise in the rate of government savings raised the aggregate savings by 4.1 percentage points, and c) an increase in the rate of household savings increased the aggregate rate of savings of China by 7.6 percentage points. The other three elements of the decomposition, namely, changing the savings rate in the corporate sector, changing the share of government in GDP, and changing the share of household consumption in GDP, played a limited or non-existent role to the change in aggregate savings. Let us consider each of the three sectors in turn.

\section{Enterprise Savings}

In the flow of funds data for China, "enterprise savings" equals the value added for both financial and non-financial companies minus labor compensation, production taxes, 
net asset payments, and net transfer payments. ${ }^{4}$ Therefore, by definition, the corporate sector has a unitary propensity to save because total corporate savings are equivalent to the "total disposable income" of the business sector, where final consumption does not take place (Ma and Wang 2010; Yang et al. 2012). From 2000 to 2008, the share of corporate income in the GDP of China rose by 5.5 percentage points, absorbing almost all the 5.7-percentage-point decline in the share of household income in GDP.

Several structural reasons contributed to the soaring profitability of enterprises in the early 2000s. By the late 1990s, China completed a series of economic reforms, including the use of labor-incentive schemes and the relaxation of worker mobility restrictions. Moreover, China implemented massive privatization of state-owned enterprises in the late 1990s, with the objectives of improving corporate governance and maintaining the competitiveness of the state sector in the national economy. As a result, the employment share of the state sector fell, its labor productivity rose, and competitive pressures spread to increase the efficiency of non-state firms (Meng, forthcoming).

However, these reforms were incomplete in a number of important ways. China continued to maintain the high-accumulation strategy that characterized the central planning era. Policies involved suppression of wage increases, low interest payments on loans, and low land rentals to subsidize enterprises. For example, state-owned enterprises financed their loans and paid their debts at interest rates significantly lower than the prevailing market rates. If the state-owned enterprises had paid market interest rates, their existing profits, and thus their savings, would have been greatly reduced (Ferri and Liu, 2010; Huang and Tao, 2010). On top of these input market distortions, the segmentation

\footnotetext{
${ }^{4}$ More specifically, asset payments include interest payments, dividends, and land rentals, whereas transfers include corporate income tax, social insurance fees, social subsidies, and social welfare payments.
} 
of rural-urban markets in the past implies the availability of massive amounts of rural unskilled labor that can migrate into cities as needed to meet industrial demand, thus decelerating urban wage growth. As a result, China in the late 1990s experienced a substantial rise in productivity, but the costs of production did not rise in a proportionate manner. The combination of these productivity-enhancing but cost-constraining reforms and policies thus increased the disposable income of enterprises despite a gradual reduction in distortions over time.

When China joined the World Trade Organization in 2001, the resulting decline in trade barriers and tariffs allowed China to experience a dramatic expansion in external demand, which became a significant factor that increased firm productivity and profits. The continued inflows of foreign direct investment, as well as the importation of sophisticated intermediate inputs, also boosted Chinese exports. Between 2000 and 2008, the growth in exports of China reached an incredible 24.8 percent per annum (NBS, 2009). The ratio of profits to industrial value added rose from an average rate of 22.6 percent from 1995 to 1999 to 34.4 percent in 2008 . The share of enterprise income in the GDP rose from 14.2 percent in the second half of the 1990 s to 22.9 percent in 2008 .

An increase in corporate profits does not necessarily imply an increase in aggregate savings rate, especially if the profits are distributed to workers or owners of the firms. In China, however, the corporate sector retained a significant amount of the increase in firm profits. In their study on the long-term wage trends in China using a national representative sample of urban households, Ge and Yang (2012) report that the average real wages increased by approximately 8 percent per annum, which is approximately 2 percentage points below the real annual growth of GDP, from 2000 to 
2007. Dividend payments rose but were still quite small, with the ratio of dividend to value added staying at less than 0.5 percent by 2007 (Yang et al., 2012). One reason for low dividends is that the Chinese government did not ask state-owned enterprises to pay dividends until 2008, although they enjoyed improved profits since the state-sector restructuring in the late 1990s. ${ }^{5}$ Moreover, private enterprises had extra incentives to save. They had to meet their funding needs through their internal savings (Song et al. 2011). This is because credit creation in China is mostly controlled by state banks, which have an intrinsic bias in favor of state-owned enterprises.

If enterprises would contribute a larger share of their profits to the household sector, aggregate savings rate would decline. Compared with firms, households have a significantly higher propensity to consume and to import. Hence, changes in policies and institutions that encourage a reallocation of enterprise income to households would reduce both the internal imbalance of extremely high national savings and its external imbalance of enormous current account surpluses.

\section{Government Savings}

Government savings in China rose from 3.28 percent of GDP in 2000 to 8.35 percent in 2008. In China, government income comes from several sources: the valueadded from the production of the state sector, income from properties, taxes on production, income taxes, and revenue from social insurance funds minus spending out of those funds. Taking these factors together, revenues of the central government nearly quadrupled from 1.891 trillion yuan in 2000 to 6.797 trillion yuan in 2008 (NBS, 2011).

\footnotetext{
${ }^{5}$ These aggregate statistics appear to be consistent with firm-level data reported by Zhang (2008), who cites that for a large sample of Chinese firms in the period of 1999 to 2003, the average and median dividends to earnings ratios were 0.35 and 0.16 , respectively.
} 
However, the pace of the increase in government spending failed to catch up with the pace of the increase in revenues.

The rise in tax revenues from production was the largest contributor to the growth in the government's disposable income during the period, accounting for 70 percent of the increase. This growth in production was spurred partly by the improving business environment and the expanding external demand that resulted from the entry of China to the World Trade Organization. However, the institutional foundation behind the rise in tax revenues linked to production can be traced to the 1994 fiscal reform. At that time, the Chinese economy had been growing for more than a decade, but much of the growth was accounted for by the non-state sector. The tax code was not designed to gather revenues from that sector, thus state revenues actually were on a declining trend starting the mid1980s. The 1994 reform aimed to boost revenue collections by the central government (Wong and Bird, 2008). From having a low net-revenue-to-GDP ratio in the early 1990s, the government posted much higher ratios from 2000 to 2008 through implementation of an effective tax system and through a robust annual GDP growth of approximately 10.4 percent.

The other major factor that contributed to the growing government surpluses was the increase in the collection of income taxes and social insurance fees outpacing its increase in spending. For example, in 2008 the Chinese government collected 1.49 trillion yuan worth of income taxes and 1.37 trillion yuan worth of social insurance fees, but it spent only 1.601 trillion yuan on social welfare payments, social insurance provisions, and other transfers. Back in 2000, revenues from income taxes and social insurance fees were only slightly higher than spending. This rise in what may be called 
"net current transfers," the excess of income and social insurance revenues over and above the amount paid out in benefits, accounted for 22 percent of the growth in government disposable income during the same period. While the accumulation of social insurance funds could reflect the effort of the Chinese government to build surpluses in anticipation of the rise in elderly dependency looming in the next decades, its actual intention could not be verified.

The pattern of substantially growing government revenues, with spending lagging behind, is consistent with the "Nation Rich, People Poor" view that is widely discussed in the public media in China. A piece of corroborative evidence is that the share of household income in the GDP declined from an average of 68 percent from 1995 to 1999 to 57 percent in 2008, whereas the share of government income rose from 17 percent to 21 percent in the corresponding periods (NBS, 2009; Bai and Qian, 2010). However, even after the recent increases in tax revenues, tax revenue as a percentage of GDP in China is still lower than those of major developed economies, such as Japan, Germany, and the U.S.

\section{Household Savings}

Household savings rate in China substantially has risen in the past three decades against the backdrop of fast income growth. In the late 1970s, household savings only accounted for 6 to 7 percent of GDP, but it had consistently grown until reaching 23 percent in 2008. Economists have studied savings in China from many perspectives, including classic life-cycle theory, permanent-income approaches, and the significance of habit formation and cultural-based explanations to saving behavior. Some of the potential 
explanations include the change in age-earning profiles for younger Chinese workers relative to older generations, the underdevelopment of the public and private pension systems in China; the effects of demographic changes like an aging population, the onechild policy, the gender imbalance; and the effects of the transition of China from public to private provision of education, health care, and housing.

As a starting point, one striking feature of Chinese household saving behavior lies in the changes in the age-saving profiles. In the late 1980s, the age-saving profile reveals a relatively flat "hump shape," resembling the typical life-cycle saving profiles observed in other advanced economies (Modigliani, 1970). However, as Figure 3 shows, the agesavings profile for the 2005-2007 period exhibits a dramatic change. These changes are seen in (a) the substantial increase in savings rates for households of all ages, and (b) the household's savings pattern turning into a "U-shaped" profile over the life cycle. That is, the young and the old saved relatively more than the middle aged. These patterns were first documented by Chamon and Prasad (2010) for selected Chinese provinces from 1995 to 2005 and later reconfirmed by Song and Yang (2010) using the national sample of the Chinese Urban Household Surveys. These features present a challenge for understanding the determination of household savings in China.

Song and Yang (2010) present a household model and show quantitatively that the dramatic rise in household savings and the corresponding changes in age-saving profiles are outcomes of two structural changes in China. First, there are large upward shifts in the earnings of successive younger cohorts of workers; meanwhile, the age-earnings profile in China at any point in time has flattened during the past two decades. These changes reflect labor market transitions from a centrally planned economy, where seniority was 
highly regarded, to a market system, where earnings reward the productive human capital of the younger generations. Second, the aggregate pension replacement rate, which is the ratio of average pension per retiree to average wages per worker in a given year, declined from approximately 80 percent in the early 1990s to a range of 52 to 58 percent in 2007 . Incorporation of these features of the Chinese economy into a dynamic optimization model of heterogeneous agents shows that these factors can explain both the recent surge in household savings and the U-shaped age-saving profiles over the life cycle.

Population control policies and the resulting demographic structural changes in China are another substantial influence on household savings. Because young population of an economy consumes without generating any income, a fall in their share in the population tends to reduce household savings rate. Moreover, because China still lacks a mature social security system, adult children often provide old-age support to their parents, in effect acting as a substitute for life-cycle savings. In an analysis rooted in these insights and using aggregate time series data, Modigliani and Cao (2004) find that demographic changes in China raised Chinese household savings through the two effects of "less mouths to feed" and old-age security. Ge et al. (2012) provide corroborative evidence through a cohort-specific analysis based on data from the Census of Population and Urban Household Surveys. They find that household savings rates increase as a result of a reduction in the number of children born in older families due to the lack of old-age security provided by their adult children. For households of younger generations, savings rates increase because of the rise in the burden of parental support as a result of the reduced number of siblings. ${ }^{6}$

\footnotetext{
${ }^{6}$ These findings are controversial: for example, it is not confirmed by aggregate panel data studies. Neither aggregate dependency ratio (Kraay, 2000) nor separate accounts of the young and the old dependency ratios
} 
The imbalanced sex ratio in China also results in a competitive motive for saving. Wei and Zhang (2011) begin by noting that that traditional preference for a son is widespread in China. Moreover, with restrictive population control policies, many families use inexpensive ultrasonic technology to detect the gender of fetuses and engage in sex-selective abortion, resulting in a severe imbalance in the sex ratio, which is defined as the ratio of males to females at specific ages. The intensified competition among men for potential wives stimulates households with a son to save and to accumulate wealth to gain a competitive edge in the marriage market. Wei and Zhang use provincial panel data (1978 to 2006) to test the effect of sex ratio imbalance on household savings. They show that the imbalanced sex ratio significantly increases household savings, with approximately 68 percent of the increase in rural savings rate and 18 percent in the urban rate being attributed to the rise in the sex ratio.

Finally, the incomplete transition from public to private provision of education, health care, and housing also contributes to the rising household savings. Several authors argue that the backwardness of financial institutions in China fails to pool risks by providing adequate medical insurance and unemployment insurance and also fails to transform savings into loans for education, housing, and other investments (for example, Woo, 2008; Chamon and Prasad, 2010). These factors might become less important over time, but matter considerably during the transition period. Lin et al. (2010) investigate the implications of the financial structure on household savings. They argue that Chinese institutions impose a dampening effect on wage growth because the labor-intensive, small

(Horioka and Wan, 2007) are found to have a significant effect on the household saving rates across Chinese provinces. Applying a cohort analysis to the data from the Urban Household Survey, Chamon and Prasad (2010) reach a similar conclusion that demographic structural shifts do not go very far in explaining saving behavior in China. 
and medium sized enterprises cannot receive adequate loans from state-dominated banks. In addition, ordinary people are not given a share in the high profits of statemonopolized industries and the natural resource sectors. The resulting higher levels of income disparity and a greater concentration of wealth to the rich tend to increase household savings. While some of the factors analysed above do not necessarily have a distinctive time effect on household savings after 2000, they have contributed to the rise in aggregate savings rate in recent years.

\section{Constraints on Investment Growth}

In 2000, on the eve of its entry into the World Trade Organization, the aggregate investment rate in China was at a trough of 35 percent of GDP (as shown earlier in Figure 2). The level of investment in China had moderated in the late 1990s, when its economy experienced deflation and over-capacity production. However, between 2000 and 2005, the investment rate began to climb rapidly along with the savings rate, before the investment rate settled into a narrow range of 42 to 44 percent from 2005 to 2008 . As noted earlier, the savings rate kept climbing higher as the investment rate plateaued. Why didn't investment keep rising?

The Chinese government exercises more effective control over investment through the state-dominated banking system than it does over savings decisions, which are more decentralized. Improvements in the investment climate, which resulted from the entry to the World Trade Organization in 2001, boosted both foreign direct investment and domestic investments in China. According to Anderson (2008), these domestic 
investments were made mostly by large state-owned enterprises and concentrated on heavy industries, such as metals, materials, machinery, automobiles, and chemical products. These investments increased production capacity, displaced imports of related products, and subsequently led to exports of surplus production.

However, in 2005, when the central government felt the need to avoid overheating of the economy, the National Development and Reform Commission issued a directive to impose controls against overinvestment with a list of "prohibited industries," which were industries that were meant to avoid further expansion. The heavy industries that had undergone dramatic expansions in capacity topped that list. Since then, with a continued fear of an overheating economy, the Chinese government sought to control the aggregate investment rate at a steady level.

Moreover, the inefficient financial system did not help find ways to funnel excess savings to profitable investment opportunities. As Song et al. (2011) explain, the stateowned banks are incapable of providing effective loans to the growing and more efficient private firms because of various legal and political problems. The immaturity of the financial system also hinders the channeling of the excess savings to education, housing, and other family-based investment loans (Woo, 2008). Chinese banks are awash with cash, but rather than investing in high-return projects of non-state enterprises or in consumer loans, the banks used the funds more to invest in low-yielding U.S. government bonds.

\section{Trade Policies}


China has vigorously pursued export promotion policies since the start of its economic reform policies in the late 1970s. In the years leading to its accession to the World Trade Organization in 2001, China practiced a combination of export promoting and import restricting policies through tariffs, quotas, and import licenses. In the early years of economic reforms, the primary concern of the government was to limit imports to avoid balance-of-payments problems resulting from excessive borrowing and trade deficits. In compliance to a membership requirement by the World Trade Organization, China phased out many of its import barriers by the late 1990s. However, a number of export-promoting strategies that were already being practiced since the 1980 s remained in place. These include the "self-balancing regulation" on the export content of foreign firms, special trade zones, liberalization of ownership restrictions on foreign direct investment, export tax rebate, and exchange rate policy. The entry of China to the World Trade Organization was a catalyst that amplified the effect of export-promoting policies and that pushed the trade surplus to an extraordinarily high level.

The "self-balancing regulation," which is part of the law governing multinational companies, requires that foreign direct investment be oriented toward export industries (Yu, 2007). A 1990 version of the implementation guideline sets an explicit rule that exports must exceed 50 percent of the total annual output of foreign firms. Although the law stating explicit restriction was relaxed in 2001, it remains in place. The share of foreign-invested enterprise in Chinese exports rose from approximately 20 percent in the early 1990 s to 56 percent in 2009 .

In the early 1980s, China established special economic zones for export in coastal cities. Owing to their initial success, special zones were expanded into inland cities. 
Multinational companies in these zones enjoy better protection of intellectual property rights, lower corporate tax rate of 15 percent, duty-free treatment of imported inputs, cheap land, and property tax-free incentive in the first five years. Additional benefits were also given to foreign firms if they export most of their products (Wang 2010). The first boom period for these zones was from 1990 to 1993, when the cumulative number of zones jumped from 18 to 130 . The second was from 1999 to 2003 , when the number increased from 139 to 196 (Sheng and Yang, 2012). A total of 221 policy zones were established in China as of 2006. Wang (2010) finds that these special economic zones attract foreign investment in export-oriented industrial enterprises. The Chinese government also gradually lifted various ownership restrictions on foreign direct investment in these zones (Sheng and Yang, 2012). Two major jumps in the list of "industries" were found in 2002 and in 2007. These nationwide initiatives on ownership liberalization raised the volume of processing export and the product varieties of multinational firms.

Export tax rebates are another trade policy tool for promoting exports. This program entails the refund of tariffs on imported inputs and value-added tax already paid on exported goods. These policies discriminate against goods sold domestically, especially goods using imported inputs, and created the incentive for firms to sell products abroad. Under conceivable circumstances, goods are sold to foreign buyers at cheaper prices. After the Asian financial crisis in 1997, China lifted the rebate rates several times, reaching an average of 15 percent in 1999, to raise the competiveness of Chinese exports before joining the World Trade Organization. The total value of the rebate payment increased substantially after China joined the World Trade Organization, 
quintupling in value from 2002 to 2008 . These tax rebates are substantial in size. In 2006, the total tax rebates for exports received by exporting firms were equivalent to 10 percent of aggregate corporate savings and approximately 14 percent of government tax revenue in the same year (Yang et al. 2012). Empirical studies show that duty drawbacks and value-added tax rebates are important in promoting exports in China (Chao et al. 2006). Although export tax rebates generally are permitted under the framework of the World Trade Organization, China uses this tool in a far more widespread and uniform way than most other countries. In a survey covering 55 developing countries, fewer than half of the countries had a legal framework or implementation regulations for their duty drawback schemes, thereby limiting its implementation (Ianchovichina, 2007).

Limits on certain imports to China also play a role in its enormous trade surpluses. China, the second largest economy in the world, is a developing country in need of advanced technology. However, in terms of trade with the U.S., Chinese imports in 15 categories of goods with the highest content of technology are far below the import of the same goods by countries such as Canada, Japan, and Holland. In fact, among the same categories of high-tech goods, the imports of China are below that of India and Mexico (Ju et al. 2011). The limited import results from the export restrictions imposed by the US government or the complicated application and approval procedures.

Finally, the role of the exchange rate policy is frequently cited in public debates as causing the current account surplus of China. Some critics and researchers argue that the pegging of the renminbi to the dollar at a low value is the reason behind the large trade surplus of China, although disagreements over the issue abound. Systematic research using the latest data has not yet established robust evidence that either exchange rate 
regimes are connected with current account imbalances or that the changes in exchange rates have led to significant adjustments in imports and exports (e.g., Corden, 2009; Cheung et. al, 2010).

Figure 4 presents the indices of renminbi exchange rate against the U.S. dollar for the 1990-2011 period, including nominal, real, and effective exchange rates. The trends in the exchange rate suggest that the sharp increase in the trade surplus of China from 2005 was not the result of a deliberate shift in exchange rate policy. From 1994 to 2005, China kept its nominal exchange rate stable at about 8.28 yuan to the dollar. During the period, China only had moderate trade surplus of less than 2 percent of GDP in most years. In July of 2005, after registering a jump in its foreign exchange reserves in the previous year, China allowed the renminbi to appreciate by 2.1 percent and embarked on a process of steady appreciation of its currency. By January of 2012, the nominal exchange rate of the renminbi against the U.S. dollar had risen by more than 30 percent. The real and effective exchange rates, which make adjustments for differential inflation in the two countries and the weighting of trade volumes, had followed a similar pattern. ${ }^{7}$ Apparently, this sizable appreciation of the Chinese currency was not enough to reverse the trend in the trade balance. Instead, the aforementioned institutional factors and other potential forces must have played a dominating role in creating the continued upsurge in the trade surplus. ${ }^{8}$ Given the analyses presented in the present paper, the exchange rate policy hardly can be the only factor driving the external imbalance, and it may well not be among the most

\footnotetext{
${ }^{7}$ See Cheung et al. (2010) and Knight and Wang (2011) for additional analyses and alternative measures of the exchange rate.

${ }^{8}$ Although some critics have not considered the realized renminbi appreciation as being sufficient, market forces have begun to operate in the opposite direction. On several occasions this year, the renminbi has fallen to the bottom of the trading band set by the Chinese government, indicating the pressure to reverse the appreciation process since 2005. In the first half of 2012, the Chinese currency has weakened by 1 percent against the dollar.
} 
important factors. Of course, this argument over causes does not rule out that a weaker currency might be part of a policy solution to address the external imbalances of China.

\section{Options for Policy Reforms}

The Chinese economy has been strongly influenced by institutions and policies that tend to favor the corporate and government sectors over the households and to promote exports. Many of these individual policies appear relatively innocuous as these are too small to significantly affect macroeconomic performance under normal circumstances. However, with the huge external shock of the entry of China to the World Trade Organization in 2001, the effect of the individual policies was amplified and the joint effects of these policies pushed the internal and external imbalances of China to gigantic scales.

Mounting pressure exists for China to rebalance its economy, which in broad terms means to adjust the sectoral distribution of income away from the corporate and government sectors and toward the household sector. The level of consumption in China

in the last few years, at roughly 47 to 50 percent of GDP, constitutes the lowest fraction of GDP recorded in any major economy. Several looming structural changes, such as slower economic growth and population aging, will likely help reduce the national savings rate of China in the future. However, these changes will likely be gradual and modest. What are the more direct reforms that could correct the imbalances of China? The coordination and timing of such reforms are complex. In what follows, I simply sketch several broad areas where I believe reforms are warranted. 
The conventional methods of rebalancing the Chinese economy often focus on government spending and the exchange rates. The Chinese government should shift the composition of its spending from investment to research and education, as its public expenditure on education as a share of GDP is still less than 4 percent, which is below the average for developing countries. Other major areas of expenditure increase should also include medical care system, pensions, social security, and other selective social programs, especially for the vast rural population. These programs can directly reduce government savings and encourage households to consume more because of reduced incentive for precautionary savings. Meanwhile, China should increase flexibility in the exchange rate of the renminbi and allow its appreciation to continue if such a direction is consistent with market forces.

While these changes to government budgets and to exchange rates are a plausible part of the overall picture, solutions to the macroeconomic imbalances in China will require a more sophisticated approach than these steps taken alone. It will require a shift in the policies and institutions that have favored production at the expense of consumption. Here are some examples:

First, the state-dominated financial system should channel more domestic savings toward high-return investment by private, small- and medium-sized enterprises, which are more labor intensive. The preferential access to credits and heavily subsidized capital financing provided to giant corporations and the state sector lead to capital misallocation with a side effect of raising corporate savings. ${ }^{9}$ Complementary to improving investment

\footnotetext{
${ }^{9}$ Using enterprise-level data on interest payments, finance costs, and total debts outstanding at the end of the year, Ferri and Liu (2010) calculated that interest rate differentials paid by enterprises of different ownership categories were substantial over the 2001 to 2005 period. The yearly average interest rates paid by state-owned enterprises fell into a narrow range of 2.23-2.86 percent, whereas the range for cooperative
} 
efficiency in production, development of the still-immature consumer loan system to help households finance education, housing, and durable goods consumption is imperative.

Second, despite the more than three decades of reforms, China still faces the challenge of reducing input market distortions and removing various impediments in market structures. Desirable policy reforms include the restoration of land prices to market values, breaking up of state monopolies in industries, such as natural resources, telecommunication, and financial services, and strengthening of corporate governance and dividend policies for both state-owned and private enterprises. These policies can facilitate the determination of enterprise profitability based on sound economic principles and lower aggregate savings with increased consumption of households and the government.

Third, the new Labor Contract Law, which took effect in 2008, should be effectively implemented. The law seeks to protect basic workers' rights, which are often abused because of asymmetric information and uneven bargaining power between employers and low-skilled workers as China becomes the workshop of the world. The enforcement of the law is particularly relevant for the approximately 150 million rural migrant workers, who still lack the full legal rights of living in cities due to the legacy of the urban household registration (hukou) system in China.

Fourth, a gradual reduction in import duty drawbacks and export tax rebates should be planned. The moderation of export promotion policy will help curtail the transfer of tax revenue to exporting firms and insert downward pressure on the prices of goods sold in the domestic market. Both of these outcomes will help stimulate consumption.

enterprises was 4.65-12.45 percent and for private firms 3.81-13.35 percent. Although the contribution of state-owned enterprises to China's GDP was around 25 percent, they received about 65 percent of total bank loans. 
Fifth, the removal of preferential policies towards export-oriented foreign direct investment, such as credit access, reduced tax rates, subsidized land prices, and lower environmental requirements, in special policy zones should be considered to set all firms in the market on an equal competitive footing. As a result, more domestic savings can be channeled to investment projects under competitive conditions, thus helping to close the savings-investment gap.

Sixth, Chinese enterprises, especially those from the private sector, should be encouraged to invest abroad. Offshore investments by Chinese firms remain very small relative to the size of the Chinese economy and its foreign exchange reserves. Diversifying the overseas asset portfolio and raising the rate of investment returns closer to the level of the domestic market of China remain a challenge.

Seventh, China should review its population control policies in the context of the anticipated rise in the elderly dependency ratio in the next four decades, which will have serious implications on savings and economic growth. The return to a healthy demographic structure can help alleviate unintended stress on the economy due to abrupt changes in population policies.

Each of these reforms, in its own way, would reduce the savings-investment gap and, together with the conventional recipes, would naturally ease the huge current account surplus of China. These suggested reforms would also help improve the efficiency of resource allocation in the Chinese economy. For economists interested in this area, there is a rich research agenda for deepening understanding of the role of these policies and institutions in the determination of savings, investment, and current account imbalances. 
The rich spatial variations across the Chinese provinces and potential international data with variations in policy intervention provide a basis for further empirical investigation.

The development over the last decade or so of an enormous gap between savings and investments, along with mammoth current account surpluses and a growing net foreign asset position, were by and large not intended or desired by China. As the imbalances rapidly developed, the complexity of the phenomena regarding the linkages of its key components, causal mechanisms, and potential remedies was not fully understood by policymakers. In addition, the hands of the Chinese government are, if not quite tied, highly restricted by past policies and institutions that tended to favor production and government at the expense of household consumption. In this sense, China is both the culprit and the victim of its own macroeconomic imbalances. 


\section{Acknowledgements}

The author would like to thank Chi Chur Chao, Hongyi Chen, Jing Han, Dong He, Jun Ma, William Martin, Liugang Sheng, Kang Shi, Yun Wing Sung, seminar participants at The World Bank and Australian National University, and the JEP editors for constructive comments and suggestions. The author is also grateful to Chuantao Cui, Shaozhi Li, and Jessie Pang for excellent research assistance. The financial support from the Research Grants Council of the Hong Kong Special Administrative Region, China (Project Number 453008) and the research support from Hong Kong Institute of Monetary Research and the Hong Kong Institute of Asia-Pacific Studies are gratefully acknowledged. 


\section{References:}

Anderson, Jonathan. 2008. "All about Rebalancing," in How to Think About China, Asian Economic Perspectives, UBS Investment Research, pp. 1-44.

Bai, Chongen and Zhenjie Qian. 2010. "The Factor Income Distribution in China: 1978-2007," China Economic Review, 21, pp. 650-670.

Bernanke, Ben. 2005. "The Global Saving Glut and the US Current Account Deficit." Speech at the Sandridge Lecture, Virginia Association of Economics, Richmond, Virginia, 10 March.

Chamon, Marcos D. and Eswar S. Prasad. 2010. "Why Are Saving Rates of Urban Households in China Rising?" American Economic Journal: Macroeconomics, 2:1, pp. 93-130.

Chao, Chi-Chur, Eden S. H. Yu and Wusheng Yu. 2006. "China's Import Duty Drawback and VAT Rebate Policies: A General Equilibrium Analysis," China Economic Review, 17, pp. 432-448.

Cheung, Yin-Wong, Menzie D. Chinn and Eiji Fujii. 2010. "China's Current Account and Exchange Rate." In Robert C. Feenstra and Shang-Jin Wei (eds.) China's Growing Role in World Trade. Chicago: The National Bureau of Economic Research (NBER), University of Chicago Press.

Corden, W. Max. 2009. "China's Exchange Rate Policy, Its Current Account Surplus and the Global Imbalances," Economic Journal, 119, pp. F430-F441.

Ferri, Giovanni and Li-Gang Liu. 2010. "Honor Thy Creditors Beforan Thy Shareholders: Are the Profits of Chinese State-Owned Enterprises Real?" Asian Economic Papers, 9:3, pp. 50-71.

Ge, Suqin and Dennis Tao Yang. 2012. "Changes in China's Wage Structure," IZA Discussion Papers, No. 6492, Institute for the Study of Labor (IZA).

Ge, Suqin, Dennis Tao Yang and Junsen Zhang. 2012. "Population Control Policies and the Chinese Household Saving Puzzle: A Cohort Analysis," IZA Discussion Papers, No. (to be assigned), Institute for the Study of Labor (IZA).

Goldstein, Morris and Nicholas Lardy. 2009. The Future of China's Exchange Rate Policy. Washington, D.C.: Peterson Institute for International Studies.

Horioka, Charles Yuji and Junmin Wan. 2007. “The Determinants of Household 
Saving in China: A Dynamic Panel Analysis of Provincial Data," Journal of Money, Credit and Banking, 39:8, pp. 2077-2096.

Huang, Yiping and Kunyu Tao. 2010. "Factor Market Distortion and the Current account Surplus in China," Asian Economic Papers, 9:3, pp. 1-36.

Ianchovichina, Elena. 2007. "Are Duty Drawbacks on Exports Worth the Hassle?" Canadian Journal of Economics 40:3, pp. 881-913.

Ju, Jiandong, Hong Ma and Ziru Wei. 2011. "Anti-Comparative Advantage: A Puzzle in US-China Bilateral Trade," Working paper, School of Economics and Management, Tsinghua University.

Kraay, Aart. 2000. "Household Saving in China," World Bank Economic Review 14:3, pp. 545-70.

Lane, Philip and Gian Maria Milesi-Ferretti. 2007. "The External Wealth of Nations Mark II: Revised and Extended Estimates of Foreign Assets and Liabilities, 1970-2004," Journal of International Economics, 73:2, pp. 223-50.

Lin, Yifu Justin, Hinh T. Dinh and Fernando Im. 2010. "US-China External Imbalance and the Global Financial Crisis," China Economic Journal 3:1, pp. 1-24.

Ma, Guonan and Yi Wang. 2010. "China’s High Saving Rate: Myth and Reality," International Economics, 122, pp. 5-40.

Ma, Guonan and Haiwen Zhou. 2009. "China's Large and Rising Net Foreign Asset Position," China \&World Economy, 17:5, pp. 1-21.

Meng, Xin. 2012. "Labor Market Outcomes and Reforms in China," Journal of Economic Perspectives," Fall Issue.

Modigliani, Franco. 1970. "The Life Cycle Hypothesis of Saving and Intercountry Differences in the Saving Ratio," in Induction, Growth and Trade, eds. W. A. Eltis, M. F. Scott, and J. N. Wolfe. Oxford: Clarendon Press, 197-225.

Modigliani, Franco and Cao, Shi Larry. 2004. "The Chinese Saving Puzzle and the Life-Cycle Hypothesis," Journal of Economic Literature 42:1, pp. 145-170.

NBS, National Bureau of Statistics of China. 2009, 2011. China Statistical Yearbook. Beijing: China Statistics Press.

SAFE, State Administration of Foreign Exchange. 2011. Data and Statistics: Balance of Payments. Available at URL: http://www.safe.gov.cn/model_safe_en/. 
Song, Zheng, Kjetil Storesletten and Fabrizio Zilibotti. 2011. "Growing Like China," American Economic Review, 101, pp. 196-233.

Song, Zheng and Dennis Tao Yang. 2010. "Life Cycle Earnings and Savings in a Fast-Growing Economy,” Working paper, Chinese University of Hong Kong.

Wang, Jing. 2010. "The Economic Impact of Special Economic Zones: Evidence from Chinese Communities," Working paper, Hong Kong University of Science and Technology.

Wong, Christine and Bird, Richard. 2008. "China's Fiscal System: A Work in Progress," In Loren Brandt and Thomas Rawski (eds.), China's Great Economic Transformation, Cambridge University Press, pp. 429-466.

Woo, Wing Thye. 2008. "Understanding the Sources of Friction in U.S.-China Trade Relations: The Exchange Rate Debate Diverts Attention from Optimum Adjustment," Asian Economic Papers 7:3, pp. 61-95.

Wei, Shang-Jin and Xiaobo Zhang. 2011. "The Competitive Saving Motive: Evidence from Rising Sex Ratios and Savings Rates in China." Journal of Political Economy 119:3, pp. 511-564.

Yang, Dennis Tao, Junsen Zhang and Shaojie Zhou. 2012. "Why Are Saving Rates So High in China?" In Capitalizing China: Translating Market Socialism with Chinese Characteristics into Sustained Prosperity, Joseph Fan and Randall Morck (eds.). Chicago: The National Bureau of Economic Research (NBER), University of Chicago Press.

Yu, Yongding. 2007. "Global Imbalances and China.” Australian Economic Review 40:1, pp.1-33.

Zhang, Haiyan. 2008. "Corporate Governance and Dividend Policy: A Comparison of Chinese Firms Listed in Hong Kong and in the Mainland," China Economic Review 19: 437-459.

Zhou, Xiaochuan. 2009. "Some Observations and Analysis of the Saving Rate Problem.” Speech at the Bank Negara Malaysia's High-Level Conference, 10 February. 
Table 1: Global Current Account Balances (Billions of US dollars)

\begin{tabular}{lccccc}
\hline \hline Country or region & 1995 & 2000 & 2005 & 2008 & 2010 \\
\hline Advanced economies: & 29.8 & -270.6 & -411.2 & -471.8 & -95.5 \\
$\quad$ Japan & 111.4 & 119.6 & 165.7 & 157.1 & 194.8 \\
$\quad$ United States & -113.6 & -416.4 & -747.6 & -668.9 & -470.2 \\
$\quad$ Euro area & 70.5 & -39.4 & 41.1 & -86.7 & 11.6 \\
$\quad$ Germany & -29.6 & -32.6 & 142.8 & 245.7 & 176.1 \\
$\quad$ Spain & -1.8 & -23.1 & -83.3 & -156.0 & -63.3 \\
$\quad-38.5$ & 65.6 & 129.7 & 126.7 & 168.4 \\
$\quad$ Other & 5.3 & 25.3 & 49.1 & 79.9 & 53.3 \\
$\quad$ Norway & -18.4 & -15.3 & -41.7 & -47.2 & -31.7 \\
$\quad$ Australia & & & & & \\
\hline & -92.2 & 95.2 & 443.0 & 704.2 & 378.1 \\
Emerging and developing economies & -36.9 & 41.7 & 167.5 & 435.9 & 308.1 \\
$\quad$ Asia & 1.6 & 20.5 & 160.8 & 436.1 & 306.2 \\
$\quad$ China & -5.6 & -4.6 & -10.3 & -24.9 & -49.0 \\
$\quad$ India & -1.2 & 80.4 & 212.7 & 343.1 & 152.8 \\
$\quad$ Middle East and North Africa & -9.9 & 2.1 & -3.4 & 0.0 & -24.9 \\
Sub-Saharan Africa & -37.9 & -48.4 & 36.3 & -31.2 & -56.9 \\
$\quad$ Latin America and the Caribbean & -10.2 & -28.9 & -57.7 & -151.3 & -76.0 \\
$\quad \begin{array}{l}\text { Central and Eastern Europe } \\
\text { Former Soviet Union }\end{array}$ & 3.8 & 48.3 & 87.6 & 107.7 & 75.0 \\
Statistical discrepancy & -175.4 & 31.8 & 232.4 & 282.6 \\
\hline \hline
\end{tabular}

Source: International Monetary Fund, World Economic Outlook Database, April 2011. 
Figure 1. International Balance of Payments of China: 1985-2010

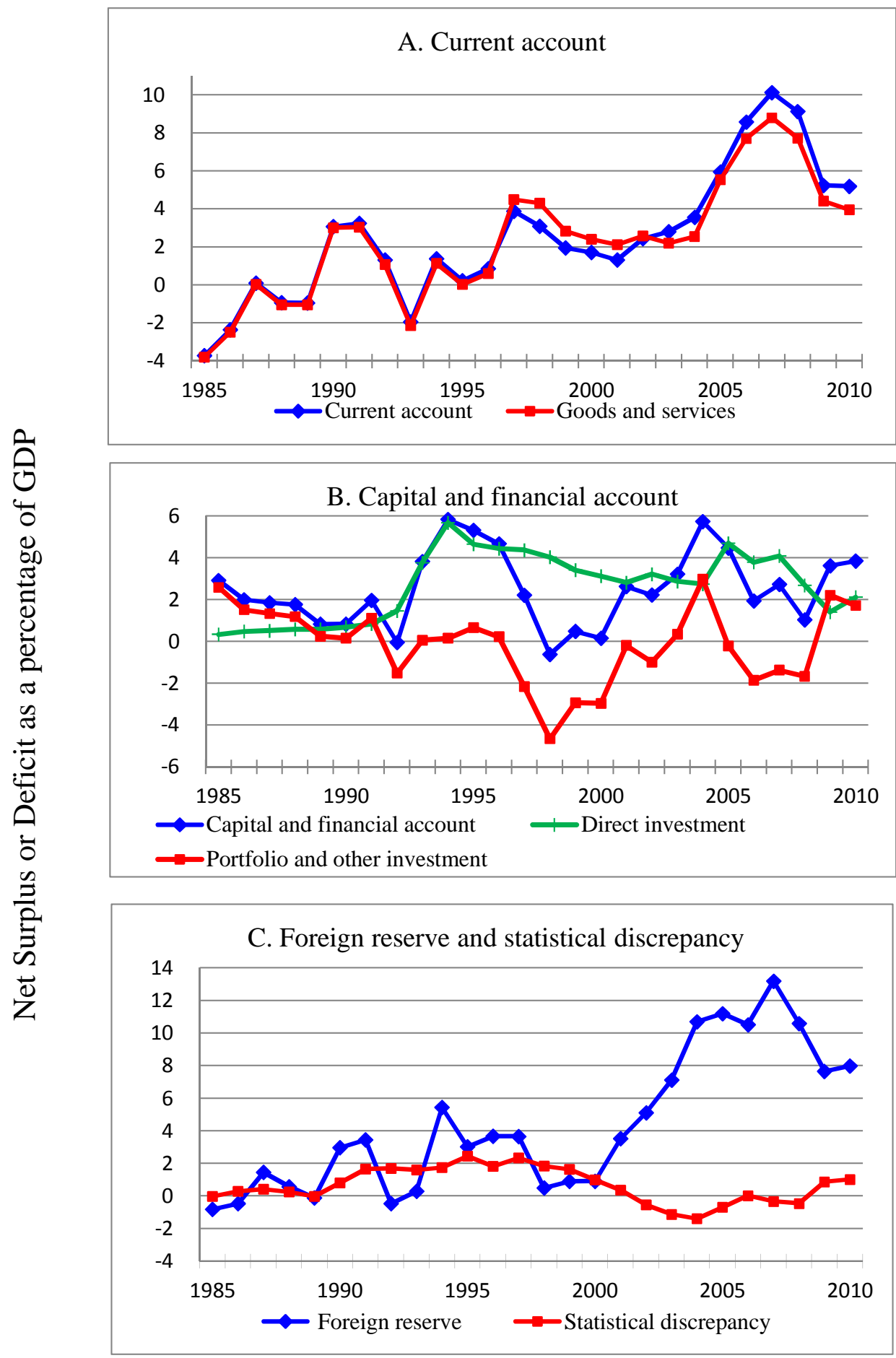

Source: State Administration of Foreign Exchange of China (SAFE, 2011). 
Figure 2. Savings and Investment in China: 1992-2008

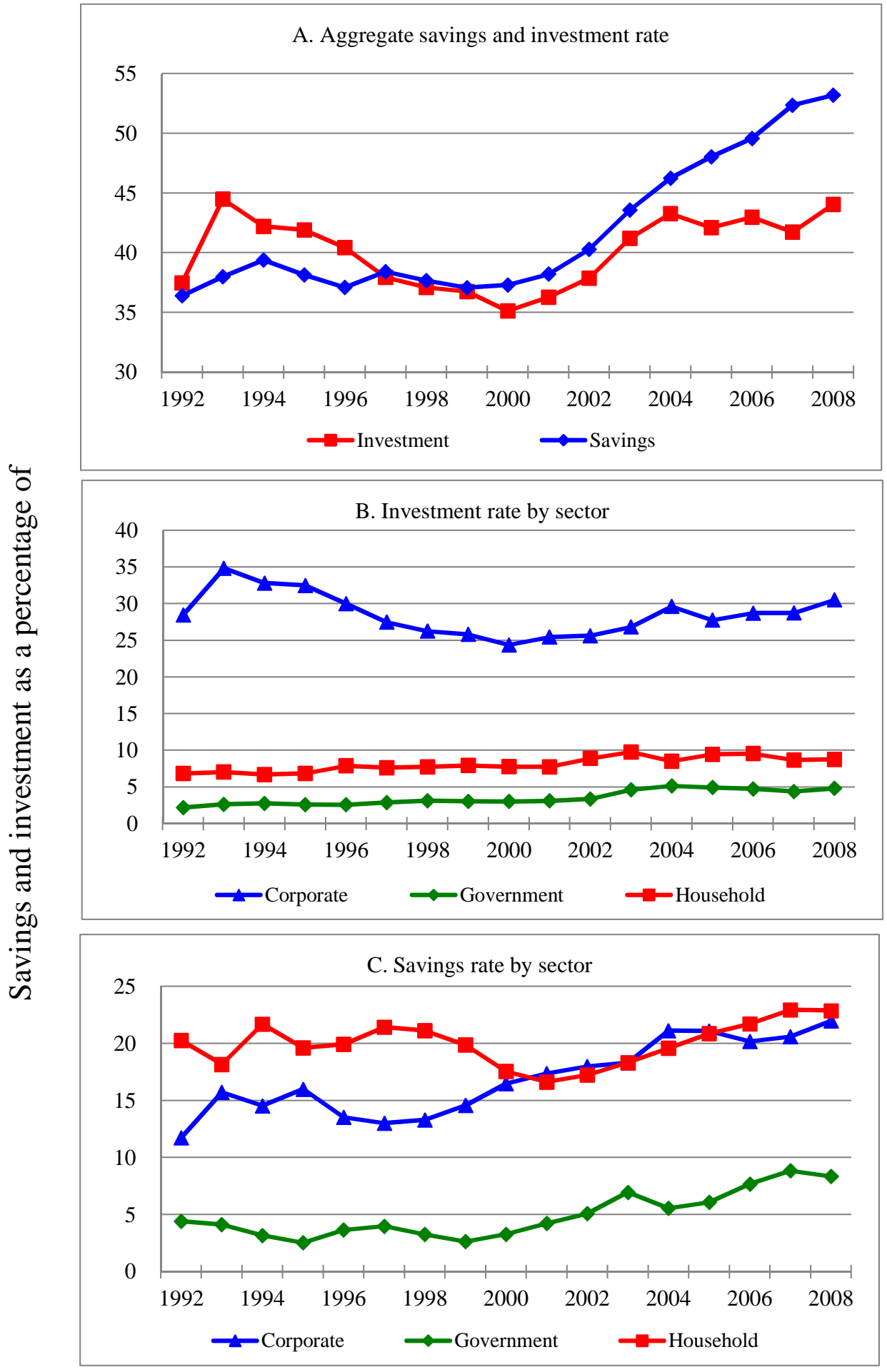

Source: Statistical Yearbook of China (NBS, 2009) 
Figure 3. Average Household Savings Rate by Age of Household Head

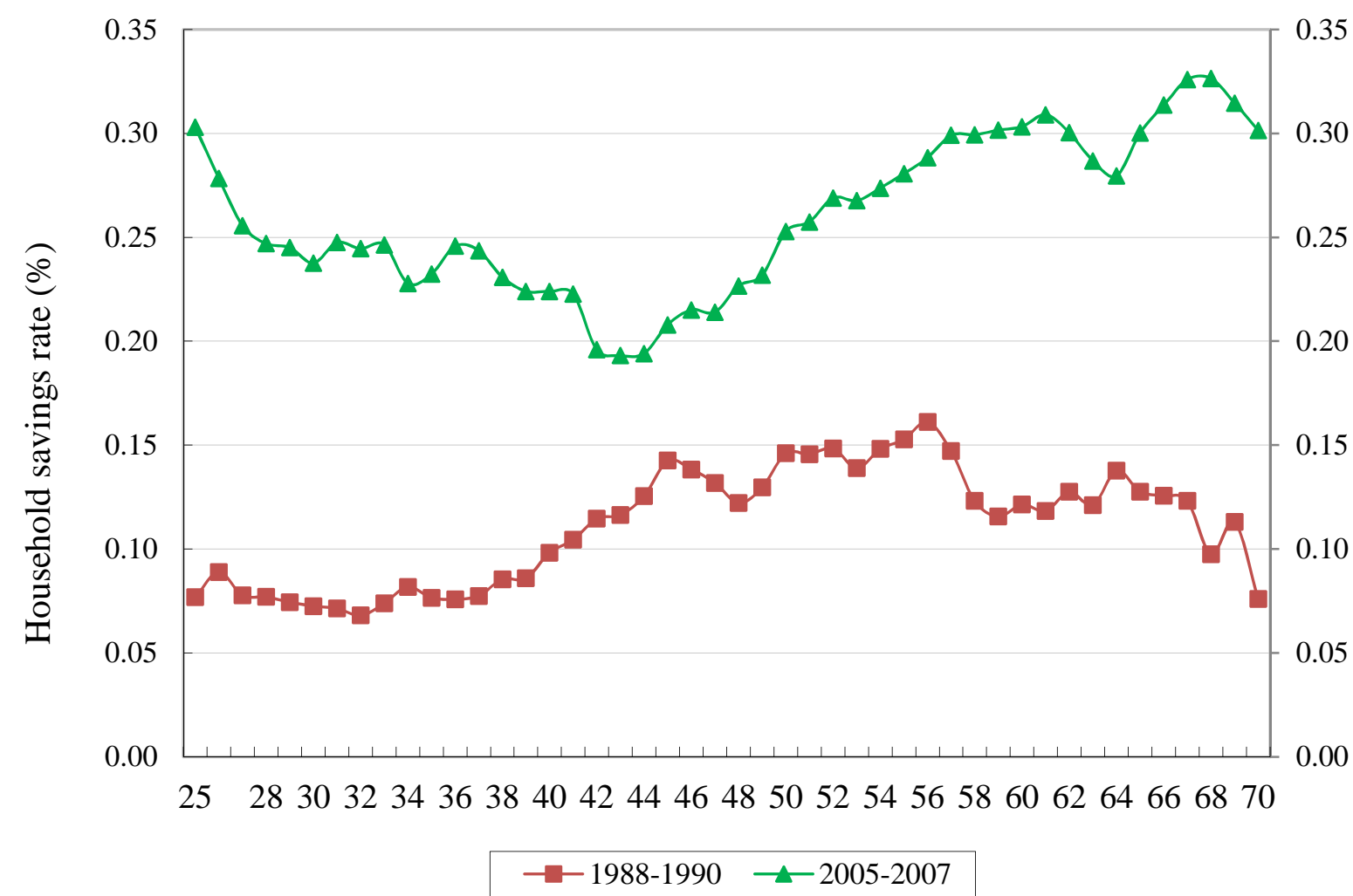

Source: Data are drawn from China's Urban Household Surveys covering five representative provinces (Liaoning, Zhejiang, Guangdong, Sichuan, and Shannxi) and a municipality (Beijing). I compute three-age moving average savings rates covering data of three-year intervals because some data cells of individual age and year have limited observations. 
Figure 4. Index of Renminbi Exchange Rate against the U.S. Dollar: 1990-2011

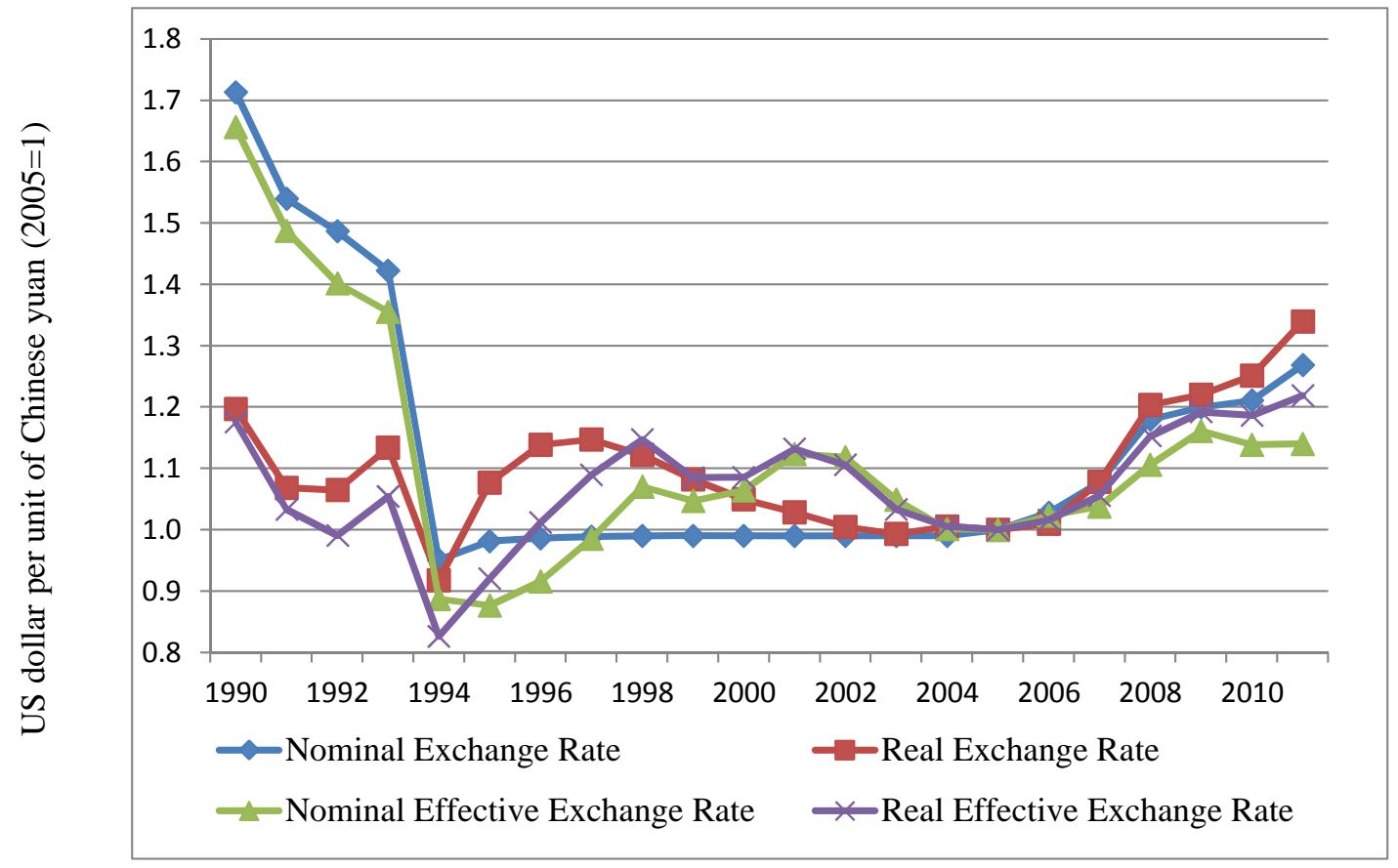

Source: Nominal exchange rate, nominal effective exchange rate and CPI-based real effective exchange rate are from IMF, International Financial Statistics. The inflation-adjusted real exchange rate is based on author's calculations. 